\title{
Moses, Elijah, and Jesus: Reflections on the basic structures of the Bible
}

\author{
Author: \\ Abraham van de Beek ${ }^{1}$ \\ Affiliation: \\ ${ }^{1}$ Systematic Theology, \\ University of Stellenbosch, \\ South Africa \\ Correspondence to: \\ Abraham van de Beek \\ Email: \\ beekavd@xs4all.nl

\section{Postal Address:} \\ Posbus 12485, Die Boord, \\ Stellenbosch 7613, \\ South Africa \\ Dates: \\ Received: 23 Nov. 2010 \\ Accepted: 25 July 2011 \\ Published: 27 Sept. 2012 \\ How to cite this article: \\ Van de Beek, A., 2012, \\ 'Moses, Elijah, and Jesus \\ Reflections on the basic \\ structures of the Bible', \\ In die Skriflig/In Luce Verbi \\ 46(1), Art. \#43, 7 pages. \\ http://dx.doi.org/10.4102/ \\ ids.v46i1.43
}

C) 2012. The Authors. Licensee: AOSIS OpenJournals. This work is licensed under the Creative Commons Attribution License.
This article deals with the end of the lives of Moses and Elijah as the representatives of the Torah and the Prophets. Moses was not allowed to enter the Promised Land, and Elijah left it before he was taken up. These events are interpreted as indicating that the Law is not able to bring the people into the Promised Land and that the Prophets cannot keep them there. The end of Moses' life is also the end of the Torah. The Prophets end with the call for a new Elijah. The Ketubim, as the human response on God's acting, do not better. The Hebrew Bible ends with the exile. The New Testament begins where the Prophets end: a new Elijah, in the person of John the Baptist. He works at exactly the place where Israel entered the land after Moses' death and where Elijah left the land. It is a reprise of the fulfilment of the promise. John points to Jesus, who begins his work at this place, not going on dry feet through the Jordan River, but fulfilling all righteousness when drawn into the water of God's judgement. Then the way to the land is open to Moses and Elijah in the glory of God on the Mount of Transfiguration, when they speak about the exodus of Jesus on the cross. Salvation is not in the law or in conversion but in being baptised into Christ in his death.

Moses, Elia en Jesus: Oorwegings oor die fundamentele strukture van die Bybel. Hierdie artikel gaan oor die einde van die lewes van Moses en Elia as die personifikasies van die Torah en die profete. Moses is verhinder om in die beloofde land in te gaan en Elijah moes dit verlaat voordat hy hemel toe gegaan het. Hierdie gebeurtenisse word so geïnterpreteer dat die Wet die volk nie in die beloofde land kan bring nie, en dat die profete hulle nie daar kan hou nie. Die einde van die lewe van Moses is ook die einde van die Torah. Die profete eindig met die oproep vir 'n nuwe Elia. Die Ketubim as die menslike antwoord op God se dade doen nie beter nie. Die Hebreeuse Bybel eindig in die ballingskap. Die Nuwe Testament begin daar waar die profete eindig: 'n nuwe Elia, in die persoon van Johannes die Doper. Hy werk op presies daardie plek waar Israel na Moses se dood die land ingekom het en waar Elia dit verlaat het. Daar is ' $n$ terugkeer na die vervulling van die belofte. Johannes wys na Jesus wat sy werk op hierdie plek begin. Hy gaan nie droogvoet deur die Jordaan nie maar gaan onder in die water van God se oordeel om alle geregtigheid te vervul. Dan is die pad na die land oop vir Moses en Elia en verskyn hulle in die glorie van God op die berg van die verheerliking, waar hulle met Jesus oor sy exodus aan die kruis praat. Redding is nie in die Wet of in bekering nie maar deurdat 'n mens gedoop word in die dood van Christus.

\section{Introduction}

A book is understood by its ending. Those who want to know the clue of a book before reading it, firstly look at the last page. The final page defines the understanding of the whole. In this article, I shall focus on the three parts of Tenach (Torah, Prophets and Ketubim) and relate them to the New Testament by paying attention to their endings - and especially to the last chapter of the Torah which is basic to the understanding of the whole Bible:

The scope of this [chapter] goes far beyond Deuteronomy itself, reaching back to the beginning of the Pentateuchal narrative (Gn 12:3; 15:1-6, 7; 17:3-8). The ending of Deuteronomy, therefore, is in an important way the ending of the Pentateuch also. (McConville 2002:478)

If it is about the Bible as a whole, we speak of a canonical reading of these texts. We deal with them as a unity. This implies that discussions about text history and originality (and what does 'original' mean?) are left out. The question is: how do the main parts of the Bible, as it is in use in the church, relate to each other, and how do these parts contribute to the understanding of the whole?

In such a discussion of the basic structure of the whole, discussions about details must be left out. These are important, of course, but in their proper place.

One of the hermeneutic circles is about the whole and the parts. Because the parts are many and the whole is only one, the former provide an abundance of issues for research. Most studies 
are concentrated on such details. However, sometimes we must turn to the whole again. Then we must leave out details because it is impossible to include them all and by consequence, if we would introduce some details, we should limit ourselves to an arbitrary selection which would not support the proposal of the whole but rather undermine it.

In this article I offer a proposal for the whole. I leave out discussions about details (and literature that refer to them). The proposal should be understood as a challenge for further research in order to confirm or to refute it. It is a systematic hypothesis in the sense of Popper: a conjecture that can be refuted or supported by subsequent investigations.

\section{Moses}

'I have let you see it with your eyes, but you will not cross over into it' (Dt 34:4). This is a shocking word of the Lord. Moses travelled with Israel to the Promised Land for 40 years. He was called to liberate the people from the house of slavery in order to bring them into the Promised Land. He endured Pharaoh's wrath. He suffered the hunger and thirst of his people. He had to deal with enemies and, worst of all, with his own people's conflicts when they grumbled against the Lord and were disobedient. But finally, after forty years, they arrive at the border of the Land to enter it. Only the river Jordan separates them from fulfilment of the promise. The Jordan near Jericho might have been broader at that time than it is now, but it is nothing compared to the sea that they crossed with dry feet. The land can be seen clearly, it can almost be touched now - and then this terrible phrase: 'You will not cross over into it' (Dt 34:4).

It seems so unjust, and 'Jewish legend and mystical speculation have spun fantastic tales around the themes of the apparent injustice of YHWH's prohibition against Moses' entry into the land' (Biddle 2003:507). No wonder, for how can one understand that Moses was not allowed to enter the land? It is amazing that many commentaries do not pay as much attention to this problem as Jewish legends do. Often the focus in the interpretation is more on Moses' remarkable death and the specific place he had as God's servant than on the problem of his not entering the land (e.g. Christensen 2002:875).

Nevertheless, the commentaries do not leave us completely empty handed. One suggestion is that it was just the normal passage of generations that ended Moses' earthly life before the entering of Canaan:

Leaders come and go. Ancestors succeed or fail. In truth, each generation stands poised to enter into God's promise, to actualize the call to be God's people, to live the authentic life described in the Torah. (Biddle 2003:510)

That is also a suggestion in a Midrash: 'It was simply Josuah's turn to lead (II, 5)' (Biddle 2003:509). It is not Moses who must serve the Lord, but Israel that is called to fidelity and obedience:
The death of Moses is therefore an essential theme of the book The challenge to Israel is to live in the land without him, but with the statutes and laws that he has given, which are able to lead to life. (McConville 2002:478)

I think this answer is too simple. It takes away the very sting of the story. According to Deuteronomy, Moses was not an old man who was worn out. 'His eyes were not weak nor his strength gone' (Dt 34:9). He was vital enough to lead Israel into the Promised Land. It is not just the passage of time that prohibited Moses to cross the Jordan. It was God's explicit prohibition: God forbade him to enter the Land. The tension rises even more if we take into consideration that Moses asked the Lord explicitly to change his decision:

I pleaded with the Lord: 'O Sovereign Lord, you have begun to show to your servant your greatness and your strong hand ... Let me go over and see the good land beyond the Jordan - that fine hill country and Lebanon.' (Dt 3:23, 25)

Moses often asked the Lord to make up his mind on behalf of his people. Moses is always successful in those intercessory prayers. The Lord listens to him and is merciful toward Israel on behalf of Moses. However, the one time Moses prays for himself, the Lord does not want to hear of it. Moses' request - that is like a child's calling on a father - is harshly refuted: "That is enough", the Lord said. "Do not speak to me anymore about this matter"' (Dt 3:26).

Why this hard refusal? McConville (2002:478-479) suggests that it is precisely Moses' intercessory role that prevents him from entering:

The topic of Yahweh's anger with Moses is (oddly) never fully explained, least of all in Deuteronomy. This only strengthens the impression that the punishment of Moses has something vicarious about it. (McConville 2002:478)

It is because of Israel's sins that Moses is not allowed to cross over to the Land. Since he takes on the responsibility for his people, as he did at Mount Sinai, he was not allowed to take part in the fulfilment of God's promises.

This befits Deuteronomy 3:26: 'For because of you the Lord was angry with me and would not listen to me.' It is due to Israel's sins that Moses is not allowed to enter the Land. That, however, is not the whole story. Numbers 20 says that it is Moses' own disobedience that made God forbid him to enter:

Because you did not trust in me enough and honour me as holy in the sight of the Israelites, you will not bring this community into the land I give them. (v. 12)

Therefore, vicarious option cannot be a sufficient explanation. Instead we should think of a participatory interpretation. Moses shares the sins of his people, not as a substitute sacrifice as McConville claims with reference to the Servant of the Lord in Deutero-Isaiah: 'There are even echoes of the Servant's death, his bearing of other's sins, and his intercessory role elaborated in Isaiah 52:13-53:12' (McConville 2002:479). Moses shares the sins of his people because he is also a sinner: 'Under his leadership, Israel sinned. Indeed, Moses himself sinned. Moses and his entire generation were not permitted entry into the land of promise' (Biddle 2003:509, 
[author's own emphasis]). When God punished the people and told them that their generation would die before the entering of the Land the only exceptions were Joshua and Caleb (Nm 14:30), not Moses.

Thus it is Moses' own sin that was the cause of God's refusal. We have to be more specific, however. It is not merely his participation in the sin of Israel as a whole. It is a very specific sin that caused the Lord's hard sentence, and this sin was committed after the announced punishment of his generation. The sin that became fatal to Moses was that he struck a rock for water, whilst the Lord had ordered him to speak to the rock. It was Moses' own anger that caused his disobedience that made the Lord angry. It was this specific sin and precisely that focus which evoked feelings of injustice, for Moses' sin seems as nothing compared to the sins that Israel committed and that Moses was willing to bear.

Moses was the humblest man that ever lived, says the Torah (Nm 12:3). He was just angry once - only once after being called to liberate the people of God, and being converted from his youthful rage against the Egyptian (Ex 2:11f.). And who cannot understand that he was so vexed after all the problems that the Israelites caused him? He always had to suffer their grumbling and yet always only sought to save them by intercessory prayers! Only once was it too much for the old man. Was he punished for this so that he could not see the fulfilment of his life's work?

We should compare his act with what Israel did - not just the generation which died in the desert, but the new generation that was at the point of entering the Land. Moses died at BethPeor. That is not a neutral name. It is the place where one of the most horrible stories of Israel's history happened: the religious orgies for the Baal of Peor (Nm 25). Whilst there was only a river between them and the fulfilment of the promises, whilst they could see the Promised Land, the Israelites gave themselves over to sexual orgies and religious prostitution on behalf of the gods of the Moabites, sharing the Moabites' beds and religion. Yet these were the people who entered the land, whilst Moses was excluded from crossing the Jordan. That is the injustice that is felt in the story.

Does the Torah end with injustice? It seems so. And if that is the conclusion of the Torah, is then therefore the whole Torah unjust?

We can only understand what happened in this last chapter of the Torah if we consider the specific relation of Moses and the Torah. Moses and the Torah belong intrinsically together, to such an extent even, that 'Moses' can be used to refer to the Torah. Moses is the Torah. He is the embodiment of God's will and as such he speaks with the Lord as a man to his friend (Ex 33:11). And precisely this relationship exacts an extremely high standard for Moses. The Shemah claims that you should love the Lord with all your heart and with all your soul and with all your strength (Dt 6:5). It is about the total person and our total life. Nothing can be excluded from the perfect love to the Lord. And precisely the person who is the most beloved makes the one who loves the most vulnerable. Two partners who lead their own lives and often share the bed with other people, get acquainted to such a lifestyle, but if the husband of a couple of perfect love and care goes astray, his wife will never overcome this. The Torah is God's expression of perfect love and Moses is the Torah in person, and he sins. Never again can he be the embodiment of the Law, for he has become a trespasser of the Law. And one who trespasses one commandment is a trespasser of the whole Law (Ja 2:9-11). That is not a private opinion of the apostle James; his words express that he is fully rooted in the Jewish tradition (Frankemölle 1994:408-409). ${ }^{1}$

Moses is a trespasser of the Law. That implies that the conclusion of the Torah is that he cannot enter the Promised Land. That is not injustice, but God's righteousness. In that way Moses is vicarious for Israel: he must bear the Law to the very end, and the curse of the Law. Not only does that say something (and more than something!) about Moses, but also about the Law, since Moses and the Law cannot be separated. It also tells us that the Law as such does not bring you into the Promised Land. If God requires perfect love, nobody, not even Moses who is the personification of the Law, will enter into the fulfilment of God's promise. It is this conclusion that Paul brings to his statement that the Law makes us conscious of sin - nobody will be justified by the Law (Rm 3:20; 7:7; Gl 3:10-11). That is not against the Law, it is the very conclusion of the Law itself.

Paul refers to Adam in relation to Moses and the Law (Rm 5:11-21). By doing so he gives a holistic interpretation of the Torah. When the Torah ends with Moses outside the land of milk and honey, it evokes the beginning of the Torah: the story of Adam, who was expelled from the garden. The cause of that expulsion was a simple sin, which was so understandable. His wife gave him a beautiful fruit. It was just a minor prohibition of the Lord that he trespassed. Eating a forbidden fruit-is that all? Angry, only once - is that all? Yes, that is all. It is death. It is dying outside the Garden and outside the Promised Land. That is the Torah from its beginning to its end, from Adam through Moses. 'All have sinned and fall short of the glory of God' (Rm 3:23).

When considering Moses' relation to Adam in the inclusion of the beginning and the end of the Torah, we must once again look to the idea of Moses' vicarious death outside the Land. He says: 'Because of you the Lord became angry with me' (Dt 3:26). Is this vicariously, however? It is not the storyteller who says this. It is Moses himself. The storyteller of the Torah says that it was Moses' own fault that made the Lord angry, because he did not trust the Lord (Nm 20:12). Thus, according to the narrator, Moses is not right when he

1.Mitton (1966:93) gives some references that Jewish rabbis made distinctions between the commandments. By keeping to more important laws, especially the Sabbath, one could compensate negligence with regard to other ones. Moo (1985:95) refers, however, to 4 Maccabees 5:19-21 where it is argued in the way of (1985:95) refers, however, to 4 Maccabees 5:19-21 where it is argued in the way of James, and Frankemolle (1994:408-409) gives many references of Jewish authors for the same. It seems to me that Mitton gives an over interpretation of the texts on the Sabbath. The aim of the rabbis is not so much to underplay the importance of other commandments but rather to stress the importance of the Sabbath. By his position Mitton is claiming that Christians like James are not casuists like the Jews. Certainly there is a lot of the casuistic amongst Jews (as there is amongst Christian as well), but that cannot not outweigh their high esteem for the Law as a whole including all its commandments. 
blames the people. He should have blamed himself. Instead, he does precisely what Adam did: 'The woman you put here with $\mathrm{me}^{\prime}$, she caused his $\sin (\mathrm{Gn} 3: 12)$. There is a full inclusion in the Torah: with Moses we are still at the same point as with Adam. There is no progress in human obedience. The Law only confirms that the promise is ineffective due to human sin: 'I have let you see it with your eyes, but you will not cross over into it' (Dt 34:4).

\section{Elijah}

In the Old Testament, after the Torah come the Prophets who are not just a continuation of the Torah. Many interpreters deal with the relation of Torah and Prophets as a modern description of history: a new period has begun. Thus one can even discuss where the demarcation line of the periods should be. For example, some authors prefer the option of a Hexateuch: the period from the promise through the entering of the Land. Such a chronological approach is different from classic Jewish thought, which is also present in the New Testament. For Jews, the Old Testament consists of three parts that each reflects a different perspective on the relation of God to his people: the Torah is the foundation, the Prophets call to maintain the law, and the Ketubim reflect the human answer in worship and wisdom. Thus we have to interpret the Prophets from the perspective of the calling to practice the Torah. Because Israel does not obey God's commandments, the Prophets are defined by the call to repent and the promise of forgiveness.

The prophet par excellence is Elijah. What Moses is for the Torah, Elijah is for the Prophets. His position is so strong that Jews put a chair ready for him at the Pesach festival: Elijah will introduce the final conversion of Israel and the coming of God's ultimate reign. And the Prophets end with the announcement of his coming (Ml 4:5-6), after a reminder of the Law of Moses and Mount Horeb (4:4). Moses and Elijah are synonymous with the Law and the Prophets.

To understand the importance of Elijah we must focus on the end of his life: he is taken away to heaven by a direct intervention of God - like Moses was buried by the Lord himself. We will focus more precisely on this event. Elijah called Israel to repentance and he had success at Mount Carmel. The people cried: 'The Lord, He is God' (1 Ki 18:39). Soon however, the euphoria evaporated. A few days later, we find Elijah in the desert, asking that he might die (1 Ki 19:5). For everything had been in vain. That is Elijah's frustration, as it is for all the Prophets. Elijah is told to go to Mount Horeb: back in the footsteps of Moses to the place where the Torah was given. At that very place he received his final orders (1 Ki 19:15-17). He makes a last roundtrip through the land, appointing successors. The last city of his trip is Jericho, the very place where Israel's journey for the conquest of the land began. Elijah is back at the beginning - coming from Mount Horeb like the people of Israel did earlier with the Torah in their luggage, the prophet of the Prophets is back at 'square one'.
What follows is shocking. Elijah goes with his successor to the Jordan River: the Prophets go the way back that Israel once went when they received the Holy Land. Upon arriving at the bank of the Jordan, Elijah takes his prophet coat and strikes the water. With dry feet they can go through the river. It is a repetition of the great day when the river water was split and the people entered the Land under Joshua. At that earlier time it were the priests who opened the way through the water (Jos 3:14-17). Now it is the prophet. But note that the direction is reversed: the prophet leaves the Land.

It is amazing that the commentaries do not pay attention to this reversed direction. Some make the comparison of Elijah and Joshua, just stressing the positive relation of both:

The author makes a connection with the glorious past, in order to show that the God of Israel is the same yesterday and today. Like He enabled men like Moses and Joshua to great things, He now does so to Elijah. (Brongers 1970: 21)

There they go: the leading prophet and his successor, who represents all successors of Elijah. They have left the Land and they cross the plain of Moab, where Israel once celebrated the festival of the Baal of Peor. Nothing has changed: Israel is still devoted to the Canaanite religion, fertility and sexuality; not acting upon the righteous decrees of the Lord but driven by sensuality and power. There they go, before them Mount Nebo, where Moses disappeared. At that very place Elijah disappears also. The Lord takes him away like He once took Moses away. The Torah ended outside the Promised Land. The prophets leave the Promised Land. The gift of the Promised Land is over - it is past time. What remains, is waiting for the exile: for none of the successors of Elijah will succeed where he failed. And none of the prophets who call for maintaining the law of Mount Horeb will succeed where the very person who received the Law failed.

The plain on the other side of the Jordan that should have led to the door of hope, ${ }^{3}$ expresses what Israel was and is: disobedient and following pagan religion of power and fertility. Neither Moses nor Elijah, neither the Law nor the Prophets can change that. The commandments do not bring the people into the Land and the call to conversion and the promise of forgiveness fail to keep them there.

So we come to the end of the Nebi' im: the prophet Malachi. He ends his short book with the announcement of a new Elijah. He will come and bring conversion - but he will do so on a day that burns like a furnace (Ml 4:1). It will destroy all opponents of the Lord. Is that a promise? Is it not rather a threat?

2.Even Brueggemann (2000:294) does not see any meaning in the story: 'Elijah acts in what must be a prophetic symbolic way, although the significance of his act escapes us.' 'The entire narrative unit is deeply enigmatic. It is impossible to understand what is happening or why the narrator includes it' (p. 295).

3. Hosea prophesies that the Valley of Achor will be a door of hope (Hs 2:15). The Valley of Achor is the place where Achan - the first person who did not keep to the the ban on Jericho - was punished to death together with his whole family (Jos $7: 24-26)$. Exactly this place will be a door of hope: the root of Israel's sin will be taken away for a new beginning. However, this promise is not fulfilled within the boundaries of the Old Testament. Hosea did not prevent Israel from being brought into exile. 
The last word of the Prophets is 'curse' (cherem). The people must convert 'or else I will come and strike the land with a curse' (Ml 4:6). This makes an inclusion from beginning to end, just as in the Torah. The Prophets begin with the ban (cherem) on Jericho (Jos 6:19-21). It should be fully destroyed as a sign that the Lord destroys the Gentiles who lived in the land. The ruins of Jericho should be the symbol of Divine judgement forever. The city might never be rebuilt. Whoever would do so, would lay its foundation and set up the gates at the costs of his sons (Jos 6:26). Such offerings of sons were a Canaanite custom, wherein major events were accompanied by the sacrifice of children. If Jericho were to be rebuilt, it would be an act that expresses that Israel is just like the pagans - and thus has lost a valid basis for a claim to live in the Land. They would be driven out and destroyed like the people who lived there before them.

It was exactly in the days of Elijah, when Ahab was king - who was married to the Canaanite princess Isabel - that Jericho was rebuilt, at the cost of the sons of the builder (1 Ki 16:34). Canaanite religion had overcome the obedience to the Law. Moses never entered the Land and the prophet Elijah had to return to Mount Horeb and his life's work ends precisely at the place of denial of the promise of the Land. When Elijah enters Jericho, he enters a place that could not exist according to God's calling. Jericho is the expression that Israel does not serve the Lord, but chooses its own gods and denies God's gracious gift.

Thus came about what Joshua, the first of the Prophets, predicted: 'You are not able to serve the Lord' (Jos 24:19). And if they are not willing to serve the Lord, it does not matter what gods they choose: gods are available at random if serving the Lord seems undesirable, 'whether the gods your forefathers served beyond the river, or the gods of the Amorites in whose land you are living' (Jos 24:15). These became the gods of the people in whose land they were living, until the gods of the land of the forefathers overcame them and brought them back to where they came from: the land of the Euphrates and the Tigris. The Promised Land was empty and new people found their place there. Again, the last word of the Prophets is 'curse'.

\section{The Ketubim}

What about the Ketubim? Is there no answer in Israel's response to God in the books of wisdom and liturgy?

The Ketubim do not contain a scene about splitting the water of the Jordan. Splitting the water is a Divine act, not a human response. Opening a way to the Promised Land is God's work, just as making the way of his judgement, when his Word leaves the land, is his acting.

There are not many references to the Jordan in the Ketubim. The books of Samuel tell about David, who symbolises Israel's response by the Psalms. After his sin against Uriah, the sword will not depart from his house (2 Sm 12:10). Absalom's revolt is the most conspicuous example of this sentence. In that story, David goes to the other side of the Jordan (2 Sm 17:22) and it is in this story that this river is frequently referred to (2 Sm 19:15-41, 20:2). The representative of the Psalms has to cross the Jordan - and returns from the Jordan. However, the books of Samuel are not part of the Ketubim, but of the Prophets. Thus the telling is rather a side effect of the Elijah story than an independent story in the Ketubim. Psalm 42 mentions the Jordan but it points specifically to the sources of the Jordan far north, near Mount Hermon (Ps 42:6). ${ }^{4}$

If God's Torah and prophetic calling do not save Israel in the Promised Land it stands to reason that we cannot expect very much from the human answer. The books of the Ketubim end with the exile (2 Chr 36). That is the end of the Hebrew Bible. It ends in the exile. To be sure, it does end with a promise (2 Chr 36:23), but one by King Cyrus, far outside the bounds of the Promised Land. The Torah does not bring you into the Promised Land. The prophetic judgement expels you from what you received by God's grace. And in the human response, crossing the border of the Promised Land does not even arise on the horizon. It all ends where it began: where Abraham was called and where the lost Paradise traditionally is located: at the rivers of Babylon.

\section{Jesus}

The beginning of the New Testament brings us back to the Jordan River. John the Baptist is preaching and baptising there. He is the new Elijah (Mt 11:14; cf. Lk 1:17). The connection of the last chapter of the Prophets and the beginning of the New Testament is remarkably close. Malachi promised a new coming of Elijah and now there he is. John is clothed like his famous predecessor in a coat of camel's hair with a leather belt around his waist (2 Ki 1:8; Mt 3:4; Mk 1:6). He is calling the people to conversion, pointing to the forthcoming wrath of God, just as Elijah did.

Now, however, everything has changed. His preaching will not be in vain, for he can point to the Lamb of God who takes away the sin of the world (Jn 1:29). He is not only calling for repentance but is also pointing to the One who is more powerful than himself, whose sandals he is not worthy to untie (Mt 3:11; Mk. 1:7; Lk 3:16; Jn 1:27). The Messiah is coming and God's kingdom will begin.

Jesus comes to the Jordan and John the Baptist witnesses about him. Jesus begins his work at the Jordan - and not just at an arbitrary place. The Gospel of John says that is was 'at Bethany on the other side of the Jordan' (Jn 1:28). It is not on the side of the Promised Land, but on the other side: the side of Moab. John, as the new Elijah, works exactly at the place where Elijah disappeared. It is here that God begins his new act. It is here where Jesus' work on behalf of the people starts. It is at the place of the orgies for the Baal of Peor; behind Jesus we see Mount Nebo where Moses died, and the plain where Elijah ascended to heaven. It is at the very place where the feet of priests touched the water in the days of Joshua and

4.There might be a slight allusion to Joshua $3: 15$ in 1 Chronicles $12: 15$ but it is certainly not a story that can be compared to the wonders of Exodus and Joshua. 
the river was opened, paving a way for Israel to enter the Promised Land. Israel is again back at the beginning, indeed, but now it will not be ineffective as it was with Moses and Elijah. Jesus is God's own coming and is the proclamation of the Kingdom of God.

Jesus comes to John. We can anticipate what should happen. The prophet takes his cloak, strikes the water and a way is opened for the Messiah, so that He can go to Jerusalem in order to take the throne of David. And more, at the very moment that the feet of Jesus touch the water, the river draws back: that the eternal High priest can enter the sanctuary according to the order of Melchizedeq, for He is the exact representation of God's own Being (Heb 1:3). He is the fulfilment of that single Psalm that sings of the Jordan River that opens a way for the power of Israel's God (Ps 114).

What we learn is that nothing like that happens! Jesus comes in order to be baptised. Even John does not understand this. It should rather be the other way around: he should be baptised by Jesus. Jesus insists: 'It is proper for us to do this to fulfil all righteousness' (Mt 3:15). Jesus is baptised. He is drawn into the water of the Jordan, symbol of all the waters and waves of God (Ps 42:7). For him there is not a dry way but $\mathrm{He}$ is drawn into the water as previously Pharaoh and the people of the old world in the days of Noah. Again, 'it is proper for us to do this to fulfil all righteousness.' This is the fulfilment of the justice of the Law: being baptised in the death of the judgement of God in the water. It is in this way that Jesus becomes the Lamb of God who takes away the sin of the world. God's new coming is not in the wonder of the Red Sea, nor in the miracle of a dry Jordan, but lies in being baptised unto death. This is the fulfilment of the promise of the Land, as given to Abraham, Isaac and Jacob.

Now that Jesus has been baptised as the beginning of his way to fulfil all righteousness, everything has changed. Everything has changed even for Moses and Elijah. The beginning of Jesus' work is his baptism. In the centre of the synoptic Gospels we find the three men together: Jesus, Moses and Elijah (Mt 17:1-13; Mk 9:2-13; Lk 9:38-36). They are in heavenly light, in the splendour of God's glory. They appear as such on a mountain in the Promised Land, maybe Mount Hermon, the old mountain of the dwelling of the gods: Jesus as the king of the Kings of the world; or rather on Mount Tabor, as the tradition says, where Barak in the power of God overcame the Canaanites (Jdg 4). Now the old religion of power and fertility will be definitively replaced by the religion of righteousness and love. The Law and the Prophets are fulfilled in the coming of Jesus, and Moses and Elijah share his glory.

The representatives of the new people of God are also present: Peter and his two fellow disciples. Peter speaks on behalf of that new people: as the rock whereon the church is built $(\mathrm{Mt}$ 16:18). 'Lord, it is good for us to be here. If you wish, I will put up three shelters, one for you, one for Moses and one for Elijah' (Mt 16:4). Suddenly the scene changes completely.
The glory disappears and Moses and Elijah are gone. What happened? What did Peter do wrong? Did he? Indeed, he did, for he did not know what he was saying (Lk 9:33).

Peter was wrong because he wanted to keep the scene of glory. He would have liked to continue it. But by doing so he did not understand what it was about. Even more: he wanted to erect three tents, one for Jesus, one for Moses, one for Elijah, as if these three were parallel, on the same level. That is the core of his mistake. This scene is not about the three but about Jesus. The voice from heaven says: 'This is my Son, whom I love; with him I am well pleased. Listen to him' (Mt 17:5).

It is the basic mistake of the church to put Moses, Elijah and Jesus on the same level. The church is inclined to keep partly to the Law, partly to the call on conversion and the promise of forgiveness, and partly to the mercy of Jesus. The church wants to organise its life partly by good works, partly by repentance and Jesus will add the rest. That is the way we will enter the kingdom of God. It is this that is the church's first response in the words of Peter. 'He did not know what he was saying,' says the gospel. At the very moment that the church wants to see more than Jesus and the Law and Prophets only as witnessing to him, the glory disappears. It is all about Jesus: Moses and Elijah just come to bear witness of him, who is the fulfilment of the Law and the Prophets. Moses and Elijah speak with Jesus about his exodus that $\mathrm{He}$ was about to bring to fulfilment at Jerusalem ( $\operatorname{Lk} 9: 31$ ). This is not the old exodus where Israel went on dry foot through the sea and Pharaoh was drowned. This is the exodus of Jesus who is drowned in the water, not just as a symbolic act, but as the beginning of his way to Jerusalem where He will fulfil everything what the Prophets have written (Lk 18:31).

The glory of Moses and Elijah is on the way to the cross. The Law and the Prophets receive the splendour of heaven now that Jesus will be crucified as the Lamb of God. And the glory of his people lies not in erecting sanctuaries for the three, but in hearing the one voice of Jesus ('Listen to Him'), being buried in his death in baptism.

The Synoptics have the turning point of their gospel in the scene on the Mount of Transfiguration. John has a similar point that is often overlooked. As noted above, he explicitly tells us that the baptism of Jesus happened at the other side of the Jordan (Jn 1:28). Jesus begins his work at the place where Israel entered the Promised Land. It is exactly this place where, according to John, Jesus begins his way to the cross. After the chapter of the good shepherd, whose voice the sheep hear, and who will give his life on behalf of his sheep, 'Jesus went back across the Jordan, to the place where John had been baptising in the early days' (Jn 10:40). It is the only other reference to the Jordan in the New Testament, beside the story of John the Baptist. Jesus begins his way to be sacrificed as the Lamb that takes away the sin of the world at the very place where Israel entered the Promised Land. His starting point is in the plane of Moab where once the tents 
were erected for the rituals of Israel's terrible sins, jointly with the pagans. Now Jesus goes as the Lamb who takes away the sin of the world - both of Israel and the Gentiles. 'And in that place many believed in Jesus' (Jn 10:42).

Jesus comes from the place where John was baptising - at Bethany on the other side of the Jordan and on the way to Jerusalem. He goes firstly to Bethany on the Mount of Olives (Jn 11:1), showing that $\mathrm{He}$ is the resurrection and the life (Jn 11:25). He does so by calling Lazarus from the tomb - and his sister Mary from her sinful life (Jn 12:1-11; cf. Lk 7:39). The Baal of Peor has gone; he has gone forever.

\section{Conclusion}

Moses liberated Israel from the house of slavery, but he could not bring them to the Land. The law of works is too demanding, even for the humblest human being. Elijah succeeded in bringing the people to the only right confession: 'The Lord, He is God,' but confessions are unable to change human lives. The only way to the glory of God is dying with Christ. Whoever dies with him can confess: 'I no longer live but Christ lives in me' (Gl 2:20). That implies that our lives are not saved because God does not take into account the stains that are still on us. We are totally righteous, free even from the smallest sin, because we belong to Christ.

Jesus' last journey is from the other side of the Jordan to Jerusalem and it ends on the Mount of Olives. It goes from Bethany by Bethany to Bethany (Lk 24:50). There is his ascension to heaven. His ascension is not in the plain of Peor, and not with a chariot and horses of fire, but on the Mount of Olives, the mount of the Messiah (Zch 14:4; Ac 1:12), blessing his people and calling his disciples to proclaim the good news of God's salvation to all nations.

The Bible does not end with a cliffhanger like the three parts of Tenach do. If we would have only the Torah it would all end in vain - outside the Promised Land. The Prophets and the Ketubim have similar endings. The New Testament ends with an inclusion of the beginning: the river of life, which evokes memories of the Garden where it all began. However, the end is much more than the beginning: the new Jerusalem, eternal life and the glory of God amongst the people.

Moses and Elijah are killed on the streets of Jerusalem ( $R v$ 11:1-14) and the gentiles are striving for power and wealth (Rv 18). They can only bring judgement on the people who dwell on earth ( Rv 11:3-6). But it is all past time, now that the book of history is given to the Lamb that is slaughtered (Rv 5:5-6). The Bible ends with this Lamb's glory for people of all nations, who are written in his book. The Old Testament ends with 'curse', the New Testament with the promise that there will no longer be any curse, whilst God's servants will reign forever and ever in the eternal day in the light of God (Rv 22:3-5).

\section{Acknowledgements Competing interests}

The author declares that he has no financial or personal relationship(s) which may have inappropriately influenced him in writing this article.

\section{References}

Biddle, M.D., 2003, Deuteronom, Smith \& Helwys Publishing Incorporated, Macon, GA. (Smith \& Helwys Bible Commentary, 4).

Brongers, H.A., 1970, 2 Koningen: De Prediking van het Oude Testament, Callenbach, Nijkerk.

Brueggemann, W.B., 2000, 1 \& 2 Kings, Smyth \& Helwys Publishing Incorporated, Macon, GA. (Smyth \& Helwys Bible Commentary).

Christensen, D.L., 2002, Deuteronomy 21:10-34:12, Thomas Nelson Publishers, Nashville, TN. (World Biblical Commentary, 6.3).

Frankemölle, H., 1994, Der Brief des Jakobus: Kapittel 2-5, Güthersloher Verlaghaus, Güthersloh/Echter Verlag, Würzburg. (Ökumenischer Taschenbuch Kommentar zum Neuen Testament, 17/2).

McConville, J.G., 2002, Deuteronomy, Apollos, Leicester/InterVarsity Press, Downers Grove, IL. (Apollos Old Testament Commentary, 5).

Mitton, C.L., 1966, The Epistle of James, Marshall, Morgan \& Scott, London \& Edinburgh.

Moo, D.J., 1985, The Letter of James, An Introduction and Commentary, InterVarsity Press, Leicester\& Eerdmans, Grand Rapids, MI. (The Tyndale New Testament Commentaries). 